\title{
Community Development: A Cross-Examination of Theory and Practice Using Experiences in Rural Malawi
}

\author{
Ignasio Malizani Jimu*
}

\begin{abstract}
The philosophy of 'community development' relates to the concept of 'locality' and people. In essence it underscores the indispensability of local needs, aspirations and local resource mobilization within geographically and socially defined spheres. Through an appraisal of community involvement in various projects, this paper interrogates the virtues of community development practices in Malawi in the last 40 years. While acknowledging that community development or local participation, as it is popularly known, is ideal in many development activities, this paper argues that participation is not a magic pill for rural development. Participation in gravity water and social action fund projects, among others, provide instances for appreciating the opportunities and the challenges of community development. One such challenge is the absence of projects that are in every sense community-driven. With few exceptions, there is no participation that is truly voluntary. Vulnerability to poverty and lack of resources at community levels defeat efforts towards genuine community development. This is a similar outcome to projects implemented under coercive rule.
\end{abstract}

\section{Résumé}

La philosophie du 'développement local' renvoie au concept de 'localité' et à celui de population. En substance, elle souligne le caractère indispensable des besoins locaux, des aspirations et de la mobilisation des ressources locales dans des domaines géographiquement et socialement bien définis. Al'aide d'une

* Ignasio Malizani Jimu is a Senior Lecturer in Human Geography at the Faculty of Education, Mzuzu University, P/Bag 201, Luwinga, Mzuzu 2, Malawi. E-mail:imjimu@yahoo.co.uk. 
analyse critique de l'implication de la communauté dans les projets de développement, ce document remet en question les vertus des pratiques liées au développement local, mises en oeuvre au Malawi au cours des 40 dernières années. Tout en reconnaissant que le développement local ou la participation locale, tel que communément connu, serait idéal pour bon nombre d'activités de développement, ce document soutient que la participation des populations à des projets pareils ne constitue pas une formule magique pour le développement rural. Par exemple, la participation à des projets d'eau de pesanteur et de fonds d'action sociale permet de se rendre compte des possibilités d'atteindre les objectifs ou de relever les défis de développement local, au rang desquels figure l'inexistence de projets de développement totalement basés sur la communauté. A quelques exceptions près, aucune participation des populations à la mise en œuvre de projets n'est faite de façon bénévole. La vulnérabilité des populations par rapport à la pauvreté ainsi que l'absence de ressources au niveau communautaire font avorter tout effort véritable de développement de la communauté. C'est le même sort qui est réservé aux projets mis en oeuvre de façon coercitive

\section{Introduction}

Rural development is commonly understood as enabling the benefits of development to reach the rural poor, a group that includes small-scale farmers, tenants and the landless (Chambers 1983), as well as the marginally employed and unemployable (Bibangambah 1985). Although the factors affecting rural development vary over space and time, rural development outcomes reflect conscious and effective redirection of investments, including capital, technology, human resources and institutions (Singh 1999), among others, in a manner that benefits those who seek a living in rural areas. Specific rural development outcomes have over time remained enhanced agricultural production of food and cash crops, improved and easy access to essential social services such as health, education, transport and safe water, and also the modernization of traditional rural structures (Arnon 1981; Chambers 1983; Singh 1999). Wherever rural development is perceived as the development of things and modernization of rural structures the balance swings in favour of the central government and external modernizing agents that include both local and international non-governmental organizations (NGOs). The outsiders draw up plans, provide funds and lead implementation of projects for the rural people portrayed explicitly or implicitly in project proposals and progress reports as beneficiaries, even when the standard term is 'clients'.

What makes community development or 'participation' a fashionable issue? First and foremost, contemporary thinking is influenced by the participatory paradigm, which rests on devolution of decision-making power. Failure of externally driven projects, lack of project sustainability and resource constraints have also popularized this shift in development thinking towards 
community or participatory approaches (Streeten 1995). Rural development initiatives (in agriculture, water supply and sanitation, education, health, etc.) are considered devoid of meaning if the ultimate stakeholders are on the receiving end. On the surface the maxim is that rural communities should be active agents in meeting developmental needs rather than waiting for the central government and other outside agents to provide what might be lacking (Mohammed 1989). In many instances NGOs are deemed as better placed to facilitate the mobilization of communities than the government (Singh 1999). Yet, some NGOs are authoritarian and inefficient as the state they are supposed to complement and sometimes displace when facilitating community development.

The goal of this paper is to show that community development is not a theory on how to develop rural areas but a means and outcome of making development possible at the level of a community. A subsidiary goal is to examine factors that lead to a situation whereby community development is rarely based on voluntary participation. Three case studies drawn from Malawi, namely, the Youth Week initiative, the Piped Gravity Water Supply Programme and the Malawi Social Action Fund (MASAF), have been selected for this purpose. Among the factors emerging from these case studies that compromise voluntarism are authoritarianism of the state, inefficiency of NGOs at mobilizing local participation, inequalities in power relations, financial and material resources constraints and vulnerability to poverty, just to mention a few. Lessons arising from the implementation of the three projects are later contextualized by drawing inferences to experiences in other parts of the developing world to demonstrate two scenarios: first, why community development rarely starts from the grassroots, and secondly, to challenge the view that community participation can be a means to all needs at the level of a community.

\section{The notion of community development}

Warburton (1998) suggested that the notion of 'community' relates to two dimensions of 'people' and 'place'. It emphasizes the relationships among people and between people and the place or locality in which people live (Worpole and Greenhalgh 1996). A 'community', upon which this contemporary development philosophy is founded, could be construed as comprising the web of personal relationships, group networks, as well as traditions and patterns of behaviour that develop against the backdrop of the physical locality and its social, economic and political situations (Flecknoe and McLellan 1994). In this context, participation is good for the residents of the locality, allowing them as principal stakeholders to influence the development path of their locality. The 'good' of the community is intrinsically 
linked with community-wide social, economic, political and environmental good, as studies on agency have demonstrated the interconnectedness of individuals and the societies or communities to which they belong. Community development is supposed to reflect people's actions and attributes of selfconsciousness. Hence, commitment to community development should recognize interconnectedness between individuals and the societies to which they belong. As Giddens and Pierson (1998: 77) argued:

Society is a structural phenomenon and that the structural properties of a group or a society have effects upon the way people act, feel and think. But when we look at what those structures are, they are obviously not like the physical qualities of the external world. They depend upon regularities of social reproduction, that society only has effects on people in so far as structure is produced and reproduced in what people do.

It follows that community development has its logical and epistemological basis in the social obligations that individuals have towards societies that nurture their talents. Participation or self-help spirit is inspired by awareness among individuals and the communities they belong to and the recognition that individuals become who they are - agents - through relationship with others (Nyamnjoh 2002: 111). As much as community life is constituted by interacting, non-independent and by mutually susceptible human beings (Barnes 2001: 348), the notion of community participation draws on independent power of individual human beings to intervene in the ongoing flow of events in their community to make a difference, to create and change social order so that collective accomplishments transcend individual hopes. The challenge is: why is voluntary participation rarely intrinsically derived?

Page (2002: 16) notes that in Anglophone Africa 'community development' is partly based on colonial tradition of 'self help', which became the main British strategy for implementation of welfare-oriented colonial development policy in the 1950s. Malawi shares in this Anglophone colonial tradition. Community development was during colonial time based on coercion and control. The native was perceive as lazy and irresponsible and had to be whipped into action. In the late 1940s and 1950s native farmers were forced to adopt draconian soil and water conservation measures. Farmers who were reluctant to follow recommended measures had their crops destroyed and sometimes were imprisoned (Nambote 1998). An alternative approach named the Master Farmer system was adopted after native resistance that were inspired by nationalist sentiments that resented anything colonial. Master farmers were usually prominent native farmers who were quite influential in particular area. The colonial government provided such farmers with seeds, fertilizer, implements such as ploughs, and advisory services. The assumption 
was that once the master farmers had adopted and implemented the innovations then neighbouring native farmers would follow suit. The intended demonstrative effect did not bear expected fruits; hence on attaining independence the concept of master farmer was abolished but the notion of community development remained intact and ingrained in the independence and later multiparty democracy rhetoric of home-grown development as illustrated by the selected case studies.

\section{The Youth Week initiative}

This was a self-help initiative coordinated by the Malawian central government through the Youth and Culture department. Rural communities were engaged in the construction of social infrastructure such as classroom blocks, health units (clinics), postal agencies, community halls, police posts, periodic markets, roads and bridges, shallow boreholes and small-scale irrigation schemes (Lwanda 1993). Between 1976 and 1985 about 6723 projects were completed countrywide. The machinery of the then ruling party, the Malawi Congress Party (MCP), played a catalytic role. The Youth League of the party was used to mobilize people at different levels to contribute labour. Primary and secondary schools were required to suspend classes for a week or more to participate in public works projects. There are few written accounts on these countrywide initiatives apart from the fact that local participation was achieved through coercion. The autocratic and one-party rule of the late Dr Banda was well known for its use of force against opponents and 'good' citizens alike (Lwanda 1993). Cross and Kutengule (2001) have summarized the effect of the political situation on community development in the following words:

From 1967, the country witnessed the beginning of a process that led to the displacement of councils with the establishment of District Development Committees (DDCs), coordinated through the Office of the President. The DDCs were linked in a hierarchical relationship with Area and Village Development Committees (ADCs, VDCs) all staffed by party cadres, with no community involvement in decision making. By the early 1970s the golden age of local government was at an end.

No wonder that the Youth Week initiative was hurriedly abandoned during the transition to multiparty democracy, since it was widely resented and some of the multiparty advocates branded the practice thangata (a colonial practice of forced labour). The initiative could not be sustained without the backing of a coercive political structure. However, a sitting of parliament in mid-2006 passed a private member's bill calling on the government to prioritize youth participation in development activities by reinstituting Youth Week, 
among other measures. The action by a democratically elected parliament to resurrect a hated scheme associated all along with autocracy underscores the folly of rejecting everything associated with past autocratic regimes just for the sake of change. It is also food for thought on the virtues of popular participation in local and national development. At the moment the challenge is how to resuscitate and manage the initiative in a democratic dispensation characterized by plurality rather than unanimity and a homogeneity of values and views.

\section{Piped gravity water Supply Programme}

This is a nationwide programme supplying portable water to rural communities from high altitude or mountain sources to the surrounding low-lying areas by the force of gravity. The first project was established during the regime of Dr Banda. A community in Chingale located to the west of Zomba, the old capital of Malawi, requested the government to provide financial support to exploit water from a nearby mountain source for domestic use. Work started in 1968 in two villages. The government provided pipes while the community supplied voluntary labour for the construction and maintenance of the project (Streeten 1995). Within a few months the project was completed, supplying water to a population of 3000 (Lindskog and Lundquist 1989). An evaluation of the project indicated that success depended on the fact that it was initiated, planned and implemented by the community. Another notable observation was that since the project was small in size work was completed within a short period of time, and the members of the community were able to reap the fruits immediately. There were also few conflicts since only two villages were involved. It is further argued that the total project cost was very low because of the use of voluntary labour (Lindskog and Lundquist 1989).

The success of the project in Chingale prompted the government to replicate the project in other areas with similar water resource endowments. Between 1969 and 1970 a bigger project was planned for Chambe (Mulanje district) to serve 30,000 inhabitants in 60 villages. Village leaders from Chambe area were taken to Chingale to appreciate and learn how the villagers in Chingale managed the project in their locality. After a visit to Chingale, the community leaders and their subjects in Chambe decided to cooperate with the government to implement a similar water supply project. However, the implementation process in Chambe was not as smooth as in Chingale. Lindskog and Lundquist (1989) stated that the project was too large for a pilot project in the area; there was also a credibility gap between what the leaders had seen at Chingale and what they were able to convey to the people in Chambe area; there were problems of retaining government field staff 
because of the remoteness of the area; there was also an issue of skills while self-help was sustainable for tasks requiring unskilled labour, it was not so suited to skilled work that was needed for a bigger project. Since the project was bigger, it took longer to finish and people's enthusiasm started to wane. In addition, clandestine political groups, which opposed the ruling Malawi Congress Party (MCP), were discouraging people, arguing that selfhelp was thangata (a colonial practice of forced labour). Despite the odds the project was completed, and began servicing over 30,000 people. On a number of occasions, however, there were quarrels over the use of water. The most common reason for the quarrels was that some beneficiaries did not work on the project despite repeated reminders. The disputes weakened community initiatives such that a chairman of one of the village development committees observed that 'internal disputes in the village are the worst enemy to development' (Lindskog and Lundquist 1989).

\section{Malawi Social Action Fund (MASAF)}

The Malawi Social Action Fund is an initiative by the government of Malawi. The scope of this project is broad since it aims at providing social infrastructure of various kinds, other than water, in rural areas through community participation. The project was launched in July 1994 with financial support from the World Bank (EIU 1999). Like the Youth Week initiative (from the 1960s to the early 1990s), the MASAF project focuses on construction of classrooms, health units, roads and bridges, police units, and teachers' houses. Rural communities are required to provide unskilled labour and building materials such as bricks, river sand and rocks worth at least 10 percent of the total cost of a project. The government provides all manufactured parts such as roof sheeting, door and window frames and electric wiring. In 1996 alone, there were 450 small-scale projects under construction (EIU 1999).

The MASAF project is now in its third phase. An evaluation of the first phase concluded that it was a success, considering that a large number of projects were completed and the quality of work was relatively good. Compared to similar projects run without community involvement, MASAF projects were more efficient in terms of resource utilization and the speed at which projects were completed. In the second phase, a further component, the Sponsored Sub-Project, was added to address the needs of vulnerable people like orphans, street children, HIV/AIDS affected, the aged and the disabled (Cross and Kutengule 2001). However, this phase was marred by political interference and rampant cases of corruption at the highest levels of government. Some funds collected from fuel levy as a MASAF safety net were not accounted for, presumably diverted for the use of the then ruling 
political party. The misappropriation of funds is reminiscent of ghost projects in the Ministry of Education, which led to the loss of over K187 million in ghost and abandoned projects (National Assembly 2000). The third phase is being implemented through district assemblies in the spirit of decentralization. District development committees (DDC) are instrumental in the screening and selection of community-initiated projects. Accountability of funds is hard to guarantee since district assemblies are currently operating without the ward councilors. The electoral commission has been unable to organize local government elections owing to lack of funding, enabling legal instruments and political bickering among parties represented in parliament. The 2005/6 budget had a provision for local government elections but the allocation was later cancelled and money diverted to provide subsidized fertilizer to enable smallholder farm households to recover from severe drought and food shortage in previous years.

The most notable and innovative feature of MASAF in its third phase is the attempt to mitigate famine by facilitating the acquisition of subsidized farmer inputs by the poorest of the rural poor. Between August and November in 2005 and 2006 MASAF implemented a money-for-assets programme to empower poor households for the growing season. Several road construction projects were completed with remarkable success and direct livelihood benefit to the poor. As opposed to normal MASAF projects where community participants were paid K43.00 per working day task (equivalent to four hours of work), MASAF doubled the working day task to eight hours of work for a fee of K200.00 per day. At individual or household level, it was anticipated that after a two-week period households would be able to earn K2000.00, which was enough to buy two bags of fertilizer weighing $50 \mathrm{~kg}$ each at a subsidized price of K950.00.

\section{Why does community development rarely start from the grassroots?}

Projects implemented under the three initiatives are all small in size, involving small sums of money and probably less significant in terms of capital, skill and managerial requirements. Less significant, though, they indicate that some rural development projects cannot get off the ground if rural people do not come forward. The project in Chingale could not begin without cooperation among the local people and with the government (Lindskog and Lundquist 1989). Likewise, MASAF-sponsored projects cannot take off if local people choose not to participate by contributing labour or basic material requirements. In a similar way, Mathur (1986) observed that plans to increase agricultural production cannot be effective if farmers are unwilling to use 
new agricultural technologies and other inputs that government extension agents propagate. These points underscore the importance of local participation and community development as a process and a measure of how much can be achieved by the people for themselves (Cohen 1996). Yet, in many cases participation is not voluntary or a reflection of selfconsciousness, but the outcome of conditioning by the social structures and regularities of social reproduction (Giddens and Pierson 1998) or sometimes extremes of vulnerability to poverty.

Hence, in many cases community development relies on imposition and reinforcement of traditional and oppressive social order upon people. Participation is sometimes based on imbalances that are manifested at three levels - a triune of the community, the family and the individual (Campbell 1994). For instance, the low social status of women, role stereotypes and the belief that awareness of the needs of the community is greater among women (Momsen 1991) tend to put the burden of community development activities on women. This is true in all water supply projects since fetching water is regarded as women's responsibility. For the good of the community, that of their families and their own good, women are compelled by circumstances and unwritten rules governing the gender allocation of tasks to take a leading role in water-related projects. Public works programmes such as food-for-work projects attract more women participants than men. Programmes that provide the option of payment in cash appear equally attractive to both men and women. From insights on gender and development in Africa, it is known that some men do not use cash income from public works to improve household welfare (Momsen 1991: 73).

Stresses of modern life also discourage community development (Taylor 1992). Zoomers (1999) has argued that communal efforts are waning as more and more traditional tasks are being eroded, resulting in increasing decommunalization or decollectivization even in the use of resources. Decommunalization in the use of resources has been observed to reduce shared values and communal cohesiveness that is central to the spirit of community participation. In the gravity water supply project in Chambe, Lindskog and Lundquist (1989) observed a situation whereby at the beginning of the project people in some villages worked hard because they thought they would get a tap outside their houses, but when they realized that the nearest tap would be 500 metres away they lost confidence in the project and their commitment to work declined during the latter part of the project. Under the one-party state, the government resorted to coercion. Coercive tactics, whether direct or indirect, prevent genuine locally initiated community projects from taking root. Instead, projects planned by the political machinery 
or the government become more common and rural people are called upon to provide labour not as partners but as agents of the political system (Lwanda, 1993). The effects of lack of voluntary participation under the Banda regime are evident now when people cannot voluntarily come forward, and instead have to be paid for working on projects that serve local needs and interests. This is not surprising since it reflects two debilitating situations that arise through lack of voluntarism (Shortall and Shucksmith 2001). The first situation relates to the absence of adequate mechanisms for horizontal coordination. The second situation is the failure to synergize local initiative with national development programmes. Hence, lack of voluntary participation in the initial stages becomes a threat to genuine community development initiatives in the later stages.

A similar outcome can occur when rural development agents are not effective and transparent when mobilizing local participation for community work. This is true for projects implemented by NGOs, community-based organizations (CBOs), faith-based organizations (FBOs), as well as some government departments. In Malawi, in the case of NGOs and FBOs in particular, local communities are sometimes considered to facilitate the transfer of money from donors who insist on community participation, particularly that of women. Afterwards there is no genuine effort to engage with the communities beyond rhetoric. Cases of ghost NGOs, CBOs and abuse of donor funding by some well-known NGOs and CBOs prove this point. Early in 2006, a consortium of over 50 NGOs lost funding from the Danish Church Aid (DCA) owing to financial mismanagement. The same grouping of NGOs was a few months later reported to have mismanaged project funds amounting to K694 million that were provided by the Norwegian and Swedish governments. ${ }^{1}$ These occurrences suggest that NGOs are hardly readable and transparent, and in this respect they cannot be trusted to build a genuine culture of community participation, whereby communities have to be involved at all stages from planning to implementation, monitoring and evaluation.

Left to themselves, most rural communities in Malawi cannot manage a participatory process. Low literacy levels and lack of financial resources, mobilization and facilitation skills are serious constraints. Time is also a major constraint for many community members juggling with other commitments - for example, to produce their own food and attend social gatherings such as initiation ceremonies and funerals that are common owing to high numbers of HIV/AIDS-related deaths. The result is that most ongoing projects operating on the principle of community participation are initiated elsewhere and by outsiders and co-optation rather than participation is the most appropriate term. Participation in such projects attracts the vulnerable who lack viable 
employment opportunities, and in the previous two to five years by challenges related to the precarious food situation. In situations where access to relief food items is dependent on willingness to provide labour in public works projects, those who come forward are the poor and hungry. However, in the case of MASAF projects, the initiative has variously been attacked for being insufficiently politically accountable, too focused on infrastructural projects and tending towards top-down management practices. A study by Cross and Kutengule (2001) observed a general feeling among the study respondents that MASAF projects suffer from political pressure. The majority of community members observed that they would rather work with chiefs than politicians in implementing the grassroots development interventions. Their rationale was that politicians either from the government or opposition side are often partisan in administering development interventions. Hence, community development becomes a battlefield where the juxtaposition of traditional leadership based on chieftancy (from village level to the level of paramount chief) and modern leadership based on political parties (from the level of branch to the national level) confront each other. Community development fails in situations where a compromise cannot be reached.

\section{Conclusion}

Although several development activities were carried out in the past and numerous others are in the offing on the principle of community participation, the results both actual and potential do not signify a breakthrough in the problem of rural development - improved and easy access to essential social services such as health, education, transport and safe water, and also the modernization of traditional rural structures, just to mention a few. The case studies cited in this paper show that community development is not specifically an economic, technical or infrastructural problem. It is a problem of matching the external support offered by rural development agents with the internal characteristics of rural systems. Hence, rural development agents should learn to 'put the last first' (Chambers 1983). In theory, the role of the central government and other outside agents should be to inspire local initiatives that improve community welfare (Passmore 1972). In practice, top-down planning and implementation of development projects have to give way to bottom-up or active community participation to achieve what Neocosmos (1998) termed 'development through negotiation'. That is, community development should be perceived not as a theory of development but a practice of development that emphasizes emancipation from inappropriate institutions and any debilitating situations that lead to cosmetic participation. Also, 
community development should be a mechanism to draw on the collective power of the members of particular communities - comprising of men and women, the rich and the poor, the able and disabled, etc. - to transform order in their locality.

\section{Note}

1. Joseph Langa, 'Another audit implicates HRCC', Weekend Nation. 13-14 May 2006.

\section{References}

Arnon, I., 1986, Modernization of Agriculture in Developing Countries: Resources, potentials and problems, New York: John Wiley \& Sons.

Barnes, B., 2001, 'The macro/micro problems and the problem of structure and agency', in Ritzer, G. and Smart, B. (eds), Handbook of Social Theory, London: Sage.

Belakere, R. and Jayaramaiah, K.M., 1997, 'Community development in droughtprone areas', Community Development Journal, 32(2): 133-140.

Bibangambah, J.R., 1985, 'Approaches to the problem of rural poverty in Africa, in Kiros', F.G. (ed.), Challenging Rural Poverty: Experiences in institutionalbuilding and popular participation for rural development in Eastern Africa, Trenton, NJ: African World Press.

Campbell, B., 1994, 'Praise the community, blame the mothers', The Independent, 30 November 1994.

Chambers, R., 1983, Rural Development: Putting the last first, London: Longman.

Cohen, S., 1996, 'Mobilizing communities for participation and empowerment', in Servaes, J., Jacobson, T.L. and White, S.A. (eds), Participation for Social Change, New Delhi: Sage, pp. 223-248.

Cross, S. and Kutengule, M., 2001, Decentralisation and Rural Livelihoods in Malawi, LADDER Working Paper No. 4 (September).

Economist Intelligence Unit, 1999, Malawi-Country Profile, London: EIU.

Flecknoe, C. and McLellan, N., 1994, The What and Why of Neighbourhood Community Development, London: Community Matters.

Giddens, A. and Pierson, C., 1998, Conversations with Anthony Giddens: Making sense of modernity, Cambridge: Polity Press.

Johnston, H., 1992, 'Rural livelihoods: action from below, in Bernstein', H., Crow, B. and Johnston, H. (eds) Rural Livelihoods: Crises and responses, Oxford: Oxford University Press in association with The Open University.

Lindskog, P. and Lundquist, J., 1989, Why Poor Children Stay Sick: The human ecology of child health and welfare in rural Malawi, Scandinavian Institute of African Studies, Uppsala, Research Report No. 85.

Lwanda, J.D., 1993, Kamuzu Banda of Malawi: A study in promise power and paralysis, Glasgow: Dudu Nsomba Publications.

Mathur, H.M., 1986, Administering Development in Third World: Constraints and choices, New Delhi: Sage. 
Mohammed, O., 1989, 'Beekeeping in a Gambian village', Community Development Journal, 24(4): 240-246.

Momsen, J.H., 1991, Women and Development in the Third World, London: Routledge.

Nambote, M.A., 1998, 'Agricultural Extension policy in Malawi: Past experiences and future directions', in Ahmed, A.G.M. and Mlay, W. (eds). Environment and Sustainable Development in Eastern and Southern Africa: Some critical issues, Houndmills: MacMillan Press Ltd in association with OSSREA.

National Assembly, 2000, Supplementary Report of the Public Accounts Committee on mismanagement of public funds in the Ministry of Education, First Report presented to the House on 19 December 2000.

Neocosmos, M., 1998, 'From peoples' politics to state politics: Aspects of national liberation in South Africa', in Olukoshi, A.O. (ed.), Politics of Opposition in Contemporary Africa. Uppsala: NAI.

Nyamnjoh, F.B., 2002, 'A child is one person's only in the womb': Domestication, agency and subjectivity in the Cameroonian grassfields', in Werbner, R. (ed.), Postcolonial Subjectivities in Africa, London: Zed Books, pp 111-138.

Page, B., 2002, 'Accumulation by dispossession: Communities and water privatisation in Cameroon', PRINWASS First International Conference on the theme 'Meaningful Interdisciplinarity': Challenges and Opportunities for Water Research, School of Geography and the Environment, University of Oxford, 24-25 April.

Passmore, J., 1972, The National Policy of Community Development in Rhodesia, Salisbury: University of Rhodesia.

Shortall, S. and Shucksmith, M., 2001, 'Rural development in practice, issues arising in Scotland and Northern Ireland', Community Development Journal 36(2): $122-133$.

Singh, K., 1999, Rural Development: Principle, policies and management, New Delhi: Sage.

Streeten, P.P., 1995, Thinking About Development, Cambridge: Cambridge University Press.

Taylor, M., 1992, 'Signposts to community development', Community Development Journal, 36(1): 42-52.

Warburton, D., 1998, 'A passionate dialogue: Community and sustainable development, in Warburton', D., (ed), Community and Sustainable Development, London: Earthscan Publishing Ltd.

Worpole, K. and Greenhalgh, L., 1996, The Freedom of the City, London: Demos. Zoomers, A., 1991, Linking Livelihood Strategies to Development: Experiences from the Bolivian Andes, Amsterdam: Royal Tropical Institute. 
